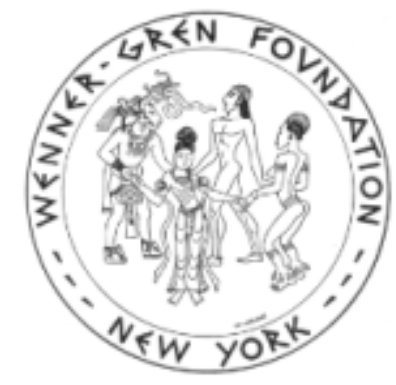

\title{
Anthropology and Brazilian Society
}

Author(s): Ruben George Oliven

Source: Current Anthropology, Vol. 30, No. 4 (Aug. - Oct., 1989), pp. 510-514

Published by: The University of Chicago Press on behalf of Wenner-Gren Foundation for Anthropological Research

Stable URL: https://www.jstor.org/stable/2743384

Accessed: 30-07-2018 11:42 UTC

\section{REFERENCES}

Linked references are available on JSTOR for this article:

https://www.jstor.org/stable/2743384?seq=1\&cid=pdf-reference\#references_tab_contents You may need to log in to JSTOR to access the linked references.

JSTOR is a not-for-profit service that helps scholars, researchers, and students discover, use, and build upon a wide range of content in a trusted digital archive. We use information technology and tools to increase productivity and facilitate new forms of scholarship. For more information about JSTOR, please contact support@jstor.org.

Your use of the JSTOR archive indicates your acceptance of the Terms \& Conditions of Use, available at https://about.jstor.org/terms

Wenner-Gren Foundation for Anthropological Research, The University of Chicago Press are collaborating with JSTOR to digitize, preserve and extend access to Current Anthropology 
Sociale Structuur van de Ambonse Eilanden $\mathrm{n}$ het algemeen en van Uli Hitu in het Midden der Zeventiende Eeuw," I 977.

9. M. K. Gautam, "In Search of an Identity: A Case of the Santal of Northern India," I 977.

ro. P. van de Velde, "On Bandkeramik Social Structure: A Case of Pot Decoration and Hut Distributions from the Central European Neolithic Communities of Elsloo and Hienheim," I980 (jointly supervised with P. J. R. Modderman).

I I. C. van Dijk, "Rebellion under the Banner of Islam: The Darul Islam in Indonesia," I98I.

I2. J. J. J. M. Wuisman, "Sociale Veranderingen in Bengkulu: Een Cultuur-Sociologische Analyse," I984 (jointly supervised with J. D. Speckmann).

I 3. J. P. M. van den Breemer, "Onze Aarde Houdt Niet van Rijst: Een Cultureel Anthropologische Studie van Innovatie in de Landbouw bij de Aouan van Ivoorkust," I984 (jointly supervised with J. D. Speckmann).

I4. L. E. Visser, "Mijn Tuin is Mijn Kind: Een Anthropologische Studie van de Droge Rijstteelt in Sahu (Indonesië)," I984.

I 5. S. A. Niessen, "Motifs of Life in Toba Batak Texts and Textiles," I985.

I6. E. Postel-Coster, "Het Onheinde Kweekbed: Machtsverhoudingen in de Minangkabause Familieroman," I985.

17. H. A. Molenaar, "Odinns Gift: Betekenis en Werking van de Skandinavische Mythologie," I985.

I 8. R. E. Jordaan, "Folk Medicine in Madura (Indonesia)," I 985 (jointly supervised with J. D. Speckmann).

19. A. Niehof, "Women and Fertility in Madura (Indonesia)," I985 (jointly supervised with J. D. Speckmann).

20. R. R. Hagesteijn, "Circles of Kings: Political Dynamics in Early Continental Southeast Asia," I985 (jointly supervised with H. J. M. Claessen).

2I. G. J. van den Broek, "Baleful Weeds and PreciousJuiced Flowers: A Semiotic Approach to Botanical Practice," I 986.

22. Ch. F. van Fraassen, "Ternate, de Molukken en de Indonesische Archipel, van Soa-organisatiek en Vierdeling: Een Studie van Traditionele Samenlevingen en Cultuur in Indonesië," I987.

23. J. Brouwer, "Coping with Dependence: Craftsmen and Their Ideology in Karnataka (South India)," I988 (jointly supervised with J. C. Heesterman).

24. J. D. M. Platenkamp, "Tobelo: Ideas and Values of a North Moluccan Society," I988.

25. Koji Miyazaki, "The King and the People: The Conceptual Structure of a Javanese Kingdom," I988.

\section{References Cited}

DE GROOT, J. J. M. I892-I9IO. The religious system of China. 6 vols. Leiden.

DE JOSSELIN DE JONG, J. P. B. I977 (I935). "The Malay Archipelago as a field of ethnological study," in Structural anthropology in the Netherlands: A reader. Edited by P. E. de Jos- selin de Jong, pp. I66-82. Koninklijk Instituut voor Taal-, Landen Volkenkunde Translation Series 17.

. I977 (1952). "Lévi-Strauss's theory on kinship and mar-

riage," in Structural anthropology in the Netherlands: A reader.

Edited by P. E. de Josselin de Jong, pp. 254-319. Koninklijk Instituut voor Taal-, Land en Volkenkunde Translation Series 17.

DE JOSSELIN DE JONG, P. E. I977. "Introduction," in Structural anthropology in the Netherlands: A reader. Edited by P. E. de

Josselin de Jong, pp. I-29. Koninklijk Instituut voor Taal-,

Land- en Volkenkunde Translation Series 17.

FRIEDERICY, H. J. I96I. De Eerste Etappe. Amsterdam: Querido. HELD, G. J. I935. The Mahabharata: An ethnological study. Amsterdam/London: Uitgeversmaatschapplij/Kegan Paul, Trench, Trubner.

LOCHER, G. W. I932. The serpent in Kwakiutl culture: A study in primitive culture. Leiden: Brill.

. I978a. "Het Leidse Perspectief," in Toen en Thans. Edited by F. Bovenkerk et al. Baarn: Amboboeken.

- 1978b. Honderd Jaar Volkenkunde aan de Leidse Universiteit. Instituut voor Culturele Anthropologie en Sociologie der Niet-Westerse Volken, Rijksuniversiteit Leiden, publ. 30.

. 1978c. Transformation and tradition. Koninklijk Instituut voor Taal-, Land- en Volkenkunde Translation Series 18.

NiEUW ENhuis, A. W. I900. In Centraal Borneo. 2 vols. Leiden. NIEUW. I907. Quer durch Borneo. 2 vols. Leiden.

RASSERS, W. H. 1959. Pandji, the culture hero: A structural study of religion in Java. Koninklijk Instituut voor Taal-, Land- en Volkenkunde Translation Series 3.

VAN WOUDEN, F. A. E. 1968 (I935). Types of social structure in Eastern Indonesia. Translated by Rodney Needham. Koninklijk Instituut voor Taal-, Land- en Volkenkunde Translation Series I I.

VERMEULEN, H. F. 1987. "P. E. de Josselin de Jong and the Leiden tradition," in Structural anthropology: Essays in honor of $P . E$. de Josselin de Jong. Edited by R. de Ridder and J. A. J. Karremans. Leiden: Brill.

ve TH, P. I. I 849-50. De Vestiging en Uitbreiding der Nederlanders ter Westkust van Sumatra. 2 vols. Amsterdam.

- 1867. Schets van het Eiland Sumatra. Amsterdam.

. 1873. Atchin en zijne Betrekkingen tot Nederland. Leiden.

- I875-82. Java: Geographisch, Ethnologisch, Historisch. 3 vols. Leiden.

WILKEN, G. A. I9I2. De Verspreide Geschriften. 4 vols. Edited by F. D. E. van Ossenbruggen. Semarang.

\section{Anthropology and Brazilian Society ${ }^{1}$}

\author{
RUBEN GEORGE OLIVEN \\ Universidade Federal do Rio Grande do Sul, \\ 906 Io Pôrto Alegre, RS, Brazil. 6 I 89
}

Anthropology in Brazil has long had relatively low status among the social sciences, and studies of the various Brazilian social groups have been secondary in importance to other themes. Today, in contrast, the question of culture is being intensively discussed in connection with the debate on the construction of a democratic Brazil and popular participation in the future of the country. The so-called New Republic that came

I. (c) 1989 by The Wenner-Gren Foundation for Anthropological Research. All rights reserved oo I-3204/89/3004-0005\$1.00. 
into being with the end of the military cycle has even created a Ministry of Culture. Accordingly, anthropology has been granted higher status, to the point that some consider it the most important of the social sciences.

Anthropology has a long tradition in Brazil (Melatti I984, Corrêa I988). As in other countries that were not colonial powers, it began with the study of Indian societies, rural groups, and eventually certain urban groups identified as disadvantaged. The object of study was, in general, "others" - those with cultures different from our own. The reports of the many Brazilian anthropologists who conducted this kind of study were frequently characterized as too descriptive and too little concerned with relating the observed phenomena to similar ones occurring in the wider society-the latter task being the concern of sociologists and political scientists.

In the I950s, Latin American social scientists in general and Brazilian social scientists in particular became increasingly concerned with economic development and underdevelopment. Rejecting explanations of underdevelopment that invoked supposed features of our culture or psychosocial characteristics of our people, they began to formulate explanations in terms of political and economic relations with the developed countries. The theory of modernization was replaced by the theory of development and later the themes of dependency and marginality, considered much more appropriate to the interpretation of Latin American social formations. Brazilian social scientists tended to seek global historical explanations, and, as one historian has put it, although the scholars involved were not, strictly speaking, historians-"'and perhaps because of this-they managed to provide an integrated view of Brazil's history" (Mota I975:18).

The rejection of culturalist theories of underdevelopment meant, however, that most social scientists abandoned the study of cultural issues-thus throwing the baby out with the bathwater (Oliven I979). For a long time anyone who involved himself with culture risked being labeled a conservative. Anthropology, with its strong culturalist bent, began to be seen as a conservative science incapable of dealing with the transformations that were occurring in Brazil. Thus the sociologist Costa Pinto (I963:78) saw serious problems not only in the "inadequacy of the anthropologists' conceptual scheme to the study of emergent problems" but also in the "difficulties they have in understanding some of the basic problems of their own traditional fields of interest and research." He continued (p. 8o).

No social scientist of any experience and intelligence, on observing the profound change and resistance to change in progress in Latin American societies ... will attempt to explain them in terms of "acculturation," "transculturation," "enculturation," "counterculturation," or any other of the notions so common a quarter of a century ago. Hence the gradual emergence of new working hypotheses, clearly sociological in character, for analyzing the de- velopment process scientifically rather than focusing on a worn-out culturalism's superficial accounts of picturesque minor aspects of this process.

The scholars who argued that cultural and psychosocial features were not the obstacle to economic growth were right. In fact, Brazil has experienced a development that has often been called "conservative modernization," in which the traditional has been combined with the modern and change articulated with continuity. While it would be pointless to return to the culturalist explanations criticized by the sociologist of a quartercentury ago, it is also impossible to account for the present Brazilian situation in terms of development, dependency, etc., alone. The situation is in reality much more complex. Today more than two-thirds of our population is urban, and most of the manufactured products that we consume are produced within our borders. We have a solid transport system and efficient communications, and the technical level of our mass media is comparable to that of developed countries. We have nuclear power stations and offshore oil platforms; we perform heart transplants, and we have more than 65 universities, many of them offering postgraduate courses. The distribution of income and property is, however, extremely uneven, $25 \%$ of the adult population is illiterate land until I985 illiterates did not have the right to vote), childhood mortality is still very high, and many Brazilians are still dying of hunger and lack of medical care.

Brazilian society is highly differentiated and multifaceted, pluricultural, plurinational, and multiethnic. In the same area live Indians, peasants, bóias-frias ("cold-grubs," low-paid fieldhands who bring their lunches from home in marmites), rural salaried workers, migrants, blue-collar workers, urban salaried workers, informal-sector workers, middle-class workers, industrialists, farmers, etc. In addition, there is ethnic diversity, represented not only by the three races that are considered to constitute the nation but also by the descendants of the European and Asian immigrants who have arrived in Brazil in the past century. Fry (I982) has reported that a rural area not more than I 50 kilometres from the city of São Paulo is distinguished by the use of a "language" of African origin. Again, in the film "Os Mukers" (The Muckers), dealing with a I9th-century millenarian revolt of German immigrants in the state of Rio Grande do Sul, the actors use a German dialect that is still spoken in that area. In addition, some 200 Indian peoples speak their own languages and are struggling to retain their lands and their cultural identities.

The nature of our national identity and the difficulty we have in accepting our cultural diversity are highlighted by what has become known as the Juruna affair. The Xavante Juruna, elected federal representative in I 982 in the name of the Indian cause but with votes from the people of Rio de Janeiro (since Indians, as illiterates, did not yet have the franchise), was denied the right to express himself in his native language in the Chamber. Attempting a speech in awkward Portuguese, he chanced to say, "Every Minister of States is a thief," 
and thereby brought on himself the threat of suit for slander. If, having mastered the codes employed in the parliamentary environment, he had said, "It is said that every Minister of States is a thief," probably nothing of the kind would have happened.

The thinking of Brazilian intellectuals on questions of culture oscillates between extremes. Sometimes our culture is severely depreciated and European or North American culture taken as a model. At other times, certain aspects of it are highly valued and popular symbols exalted (Oliven I986). The same oscillation can be seen in respect to identification of the sources of Brazilian culture and, in the final analysis, determining what that culture is. According to one view, Brazilian culture is the intellectual and artistic productions of the elite. A supposedly alternative view is that the cultural manifestations of the popular classes are its real roots, but this judgement arises out of nostalgia and vanity. Thus some of our intellectuals have risen to the "defence" of popular culture against the attacks that progress is supposed to be making on it, adopting a paternalistic and essentially curatorial posture. In effect, Brazilian culture according to the first view is Culture with a capital C, produced by a narrow social group but claimed to be valid for the whole nation. Conversely, according to the second, culture is a crystallized image of the cultural manifestations developed by our dominated classes in the past.

Simultaneous with the formation of these two images has been a process whereby cultural manifestations once restricted to certain social groups are adopted by the rest of society and turned into national symbols (Oliven I984a). The dominant classes may appropriate, reelaborate, and eventually transform into a national symbol a cultural manifestation that was originally restricted to the popular strata and often repressed by the state, for example, the samba, malandragem (Oliven I984b), candomble and Umbanda, and feijoada. Alternatively, the popular classes may appropriate, reelaborate, and eventually transform into a national symbol a cultural manifestation that was originally restricted to the dominant strata and often considered a mark of distinction, for example, soccer and carnival (Pereira de Queiroz I980, von Simson I98I). Common to the two movements is the appropriation of specific elements and their recodification and use in a new context in a way that alters their meaning. Indeed, this process of resemantization is much more complex than is apparent at first glance, because besides the relationship between popular culture and dominant culture it includes the intervention of the state and the action of the mass media.

It might be argued that this appropriation of cultural manifestations and their subsequent transformation into symbols of national identity is one of the distinctive features of Brazilian cultural dynamics. This is not to say that it is absent in other cultures (jazz in the United States and the tango in Argentina are examples), but it seems to be much more intense in Brazil. In many developed countries with a democratic tradition, social differences have been substantially reduced and access to eco- nomic benefits and civil rights broadened while cultural boundaries have remained well delineated. (This may be observed both in relatively new societies such as those of North America and in older ones such as Britain.) In Brazil, in contrast, huge social and economic differences persist, and there is a tendency for cultural manifestations to be transformed into symbols that contribute to social cohesion.

Brazilian society is today engaged in reconstructing a democratic order and reducing social and economic inequalities. The difficulty it has in accepting its cultural diversity, however, causes the term "democracy" to be frequently misunderstood as a synonym for "consensus" and "homogenization." In seeking to eliminate inequalities we end up disregarding cultural and political differences-and this, as our historical experience has taught us, is a sure way to totalitarianism. Similarly, "hegemony" is often misunderstood as a synonym for "standardization" almost to the point of "coercion." Whatever one's definition of hegemony, however, it is certainly the opposite of standardization and involves the ability of a class or group, through political and moral leadership, to articulate diverse elements. As a consequence of this series of misunderstandings, democracy is often more a memory than an effective practice. This is important because in times of crisis the demand for efficacy may cause democracy to be postponed in favor of authoritarianism in everyday life. History, once again, has shown us that democracy has to be nurtured at the grass roots, as daily practice.

It is precisely with the struggle for democracy and the political "opening" that marked the end of the military cycle that culture began to become more visible in Brazil. The popular movements that sprang up tended to be more concerned with issues often considered local and minor (albeit basic) than with the great traditional themes of development, the state, and class struggle. New political actors emerged and new social identities began to be constructed-age-related (represented, for instance, by youth as a social category), sexual (represented by the feminist movement and the homosexual movement), religious (represented by the growth of the socalled popular religions, Umbanda and Pentecostalism), regional (represented by the revival of regional cultures and calls for administrative decentralization [Oliven I987]), and ethnic (represented by the growth of the black movement [Borges Pereira I983, Seyferth I983] and the increasing organization of Indian societies [Santos I982]). Because identities are formulated in opposition or contrast to other identities, this process involved the elaboration of features of Brazilian culture that were appropriated for use as signs of distinction. What was happening, ultimately, was the rediscovery of differences-and not by intellectuals but by social movements.

Brazilian social scientists have for the most part remained more or less indifferent to this cultural effervescence. Anthropologists, in contrast, trained in the study of culture, have become increasingly aware that many of their concerns in relation to simple societies 
can be applied to the understanding of the dynamics of urban-industrial ones. The cultural manifestations of different social groups have been recognized as constituting a rich and virtually unexplored field of social research in a milieu characterized by global interpretations of historical process. Because their training tends to emphasize the integration of spheres of social life and what Mauss called "total social facts," anthropologists have found that it is possible to study Brazilian society from a new perspective.

Thus the concern with putting oneself in the other person's place that is part of the anthropologist's enculturation has been transferred with great success to the study of the processes that make up daily life. Finding a strangeness in what is familiar has proved to be a good way to understand Brazilian society. In fact, representations of Brazilian society can frequently be observed in spheres that were until recently despised. For example, the great national rituals of carnival, the Independence Day parade, and the religious festivals are "basic ways in which so-called Brazilian reality unfolds before itself" (Da Matta I979:35). Examination of these rituals shows how Brazilians represent their society and dramatize its contradictions. The same may be true of soccer, but despite its tremendous popularity there is not much research on it from this point of view. The anthropological studies that exist (Soares 1975, I979; Neves 1979; Araújo I982; Da Matta et al. I982) indicate that, like cockfighting in Bali (Geertz I975), it may shed some light on Brazilian culture. Similarly, although television soap operas are viewed by literally millions of Brazilians, there are practically no studies of this genre. One of the few (Leal and Oliven I988) shows that the "social reading" of soap operas varies by class.

Whereas Brazilian social science has tended to ignore the middle class, considering it not really a social class in the strict sense of the term, anthropological studies have shown the importance of the urban middle class in providing insights into the family, kinship, and the notions of "person" and "individual" (Velho I98I) in Brazil. Work on sex roles and the position of women in our society has shown how feminine identity is constructed in Brazil and explored the opposition of public and private domains, associated with masculine and feminine worlds, respectively (Franchetto, Cavalcanti, and Heilborn I98I). The construction of feminine identity is, of course, pervaded by the class structure. Accordingly, among the concerns of Brazilian anthropologists is to compare upper- and middle-class with working-class families (Corrêa I982, Durham I980) and to understand the importance of kinship in Brazil today (Abreu Filho I982).

Anthropology has given considerable attention to the way of life of the working class, producing studies of peasants (Soares I98I), migrants (Menezes I976), miners (Eckert I985), and blue-collar workers (Lopes I978, Macedo I979) as well as research on popular culture (Arantes I982; Brandão I98I; Magnani I982; Oliven I984b, I988; Ortiz I980). This latter research has approached these cultural forms not as autonomous but as part of an increasingly complex society characterized by constant interaction between popular culture and the mass media and an articulation of "traditional" with "modern."

Brazilian reality tends to challenge many of the propositions advanced in the literature about the consequences of urban life. Thus, for example, secularization is frequently considered an inevitable consequence of urbanization, but the situation is much more complex than this. While the introduction of capitalist relations probably leads to religious change, this is not necessarily secularization, nor is there any relation between this process and urbanization. The remarkable expansion of popular religions such as Umbanda and Pentecostalism (Fry and Howe 1975, Ortiz I978) precisely in the more developed cities of Brazil makes this clear. Similarly, there is a whole school of thought-inspired in its more conservative form by the Chicago School and in its more progressive form by the Frankfurt-that postulates that the development of urban-industrial society tends to destroy cultural traditions and impose a culture standardized by the mass media and a homogenization of attitudes, values, and behaviour. In fact, however, the cultural dynamics of Brazilian cities involve vigorous dialogue between popular and urban-industrial culture (Oliven I 980). The city of São Paulo, centre of the Brazilian economy, is a case in point. Alongside of the mass media is a multiplicity of popular and regional cultural manifestations including more than 200 circuses (Magnani I984).

Numerous writers have argued that, despite the heterogeneity of its social structure, a complex society tends to become culturally homogeneous. The issue is, however, not that simple; the members of a complex society do indeed share a cultural heritage, but they differ in many ways. There is constant negotiation of social identities formulated in terms of differences. Because the anthropological approach focuses on differences, it is increasingly being recognized as of fundamental importance for the study of contemporary Brazilian society. Especially in the light of the rapidity with which that society is changing, the study of the customs and cultural orientations of various social groups is important for reflecting and mediating its contradictions.

\section{References Cited}

ABREU FILHO, OVIDIO DE. I982. Parentesco e identidade social. Anuário Antropológico 80:95-I I 8.

ARANTES, ANTONio Augusto. 1982. O trabalho e a fala. São Paulo: Kairós.

ARAúJo, RiCARDo benzaquen. 1982. Força estranha. Ciência Hoje I $(\mathrm{I}): 32-37$.

BORGES PEREIRA, JOÃO BAPTISTA. I983. Negro e cultura negra no Brasil atual. Revista de Antropologia 26:93-ro5.

BRANDÃo, CARLOS RODRIGUES. I98I. Sacerdotes de viola. Petrópolis: Vozes.

CORRÊA, MARIZA. Editor. 1982. Colcha de retalhos: Estudos sobre a familia no Brasil. São Paulo: Brasiliense.

. I988. Traficantes do excêntrico: Os antropólogos no Brasil dos anos 30 aos anos 6o. Revista Brasileira de Ciências Sociais $3(6): 79-98$. 
Costa pinto, L. A. I963. Sociologia e desenvolvimento. Rio de Janeiro: Civilização Brasileira.

DA MATTA, ROBERTO. I973. Ensaios de antropologia estrutural. Petrópolis: Vozes.

. I979. Carnavais, malandros e heróis. Rio de Janeiro: Zahar.

DA MATTA, ROBERTO, LUIZ FELIPE BAETA NeVES, SimoNi LAHUD GUEDES, AND ARNO VOGEL. I982. O universo $d o$ futebol. Rio de Janeiro: Pinakotheke.

DURHAM, EUNICE. I980. A familia operária: Consciência e ideologia. Dados 23:201-I3.

ECKERT, CORNELIA. I985. Os homens da mina: Um estudo das condições de vida e das representações dos mineiros de carvão de Charqueadas, RS. Master's thesis, Universidade Federal do Rio Grande do Sul, Pôrto Alegre, RS, Brazil.

FRANCHETTO, BRUNA, MARIA LAURA V. C. CAVALCANTI, AND MARIA LUIZA HEILBORN. Editors. I98I. Perspectivas antropológicas da mulher. Rio de Janeiro: Zahar.

FRY, PETER. I982. Para inglês ver. Rio de Janeiro: Zahar.

FRY, PETER, AND GARY NIGEL HOWE. I975. Duas respostas ã aflição: Umbanda e Pentecostalismo. Debate e Critica 6:7594.

GEERTZ, CLIFFORD. I975. The interpretation of cultures. London: Hutchinson.

LEAL, ONDINA FACHEL, AND RUBEN GEORGE OLIVEN. I988. Class interpretations of a soap opera narrative: The case of the Brazilian novela "Summer Sun." Theory, Culture, and Society 5(I):8I-99.

LOPES, JOSE SERGIO LEITE. I978. O vapor do diabo: $O$ trabalho dos operários do açucar. Rio de Janeiro: Paz e Terra.

MACEDO, CARMEN CiNiRA. I979. A reprodução da desigualdade: O projeto familiar de um grupo operário. São Paulo: Hucitec.

MAGNANI, JOSE GUILHERME CANTOR. I982. Cultura popular: Controvérsias e perspectivas. Boletim Informativo e Bibliográfico de Ciências Sociais 1 2:23-29.

. I984. Festa no pedaço: Cultura popular e lazer na cidade. São Paulo: Brasiliense.

MELATTI, JULIO CEZAR. I984. A antropologia no Brasil: Um roteiro. Boletim Informativo e Bibliográfico de Ciências Sociais I 7:3-52.

MeneZeS, Claudia. 1976. A mudança: Análise da ideologia de um grupo de migrantes. Rio de Janeiro: Imago.

MOTA, CARLOS GUILHERME. 1975. A historiografia brasileira nos últimos quarenta anos: Tentativa de avaliação critica. Debate e Critica 5:I-25.

NeVeS, LUiz Felipe BAetA. 1979. O paradoxo do coringa. Rio de Janeiro: Achiamé.

OLIVEN, RUBEN GE ORGE. 1979. Culture rules OK: Class and culture in Brazilian cities. International Journal of Urban and Regional Research 3(1):29-48.

- I980. Urbanização e mudança social no Brasil. Petrópolis: Vozes.

. I $984 a$. The production and consumption of culture in Brazil. Latin American Perspectives I I (I): I03-I 5 . I $984 b$. A malandragem na música popular brasileira. Latin American Music Review 5(r):66-96.

- I986. State and culture in Brazil. Studies in Latin American Popular Culture 5:180-85.

. I987. The growth of regional culture in Brazil: An analysis of the resurrection of gaúcho identity in an urbanized state. Canadian Journal of Latin American and Caribbean Studies I 2: I09-I 4.

. I986. "The woman makes (and breaks) the man": The masculine imagery in Brazilian popular music. Latin American Music Review 9(I):90-108.

ORTIZ, RENATO. I978. A morte branca do feiticeiro negro: Umbanda, integração de uma religião numa sociedade de classes. Petrópolis: Vozes.

- I980. A consciência fragmentada. Rio de Janeiro: Paz e Terra.

PEREIRA DE QUEIROZ, MARIA ISAURA. I980. Evolução do carnaval latino-americano. Ciência e Cultura 32:1477-86.
SANTOS, Silvio COELHO. I982. O indio perante o direito. Florianópolis: Editora da UFSC.

SEYFERTH, GIRALDA. I983. Etnicidade e cidadania: Algumas considerações sobre as bases etnicas da mobilização politica. Boletim do Museu Nacional 42: I-I6.

SOARES, LUIS EDUARDO. I975. Futebol e ideologia. Revista de Cultura Vozes 69(3):67-69.

. I979. Futebol e teatro: Notas para uma análise de estratégias simbólicas. Boletim do Museu Nacional 33: I-22. . I98 I. Campesinato: Ideologia e politica. Rio de Janeiro: Zahar.

VEL HO, Gil BeRto. I98I. Individualismo e cultura. Rio de Janeiro: Zahar.

VON SIMSON, OLGA R. DE MORAES. I98I. Transformações culturais, criatividade popular e comunicação de massa: $O$ carnaval brasileiro ao longo do tempo. Cadernos CERU I4:43-56.

\section{Sample Size and Research Strategy in Cultural Anthropology ${ }^{1}$}

THOMAS SCHWEIZER AND HARTMUT LANG Völkerkundliches Institut, University of Tübingen, Schloss, D-7400 Tübingen I/Institut für Völkerkunde, University of Cologne, Albertus-Magnus-Platz, D-sooo Cologne 4I, Federal Republic of Germany. I II 89

Statistics textbooks argue with good reason that sample size should be determined by the statistical situation at hand. In cultural anthropology, however, sample size is given and, moreover, generally small. In contrast to the samples of other disciplines, which are often as large as I, 000 or more cases (in survey research, for instance), samples in anthropology are rarely larger than 500 and generally smaller than 200 cases, as few as 30 being not uncommon. The obvious answer to the problem of sample size would be to try harder to conform to the statistical rule, but this seems to us to have little prospect of success. Data collection in the subfields of cultural anthropology, such as demography, economics, ecology, and social organization, is becoming more and more demanding, and there is a newly awakened concern for the quality of primary data (Bernard et al. I986). These considerations limit the size of the data sets generated in anthropological field research. In statistical crosscultural studies, Galton's problem-the disturbing effect of cases that are historically linked by common origin-limits sample size by requiring the exclusion of such cases (or those connected spatially, by way of diffusion [see Schweizer 1987:chap. 5]). New network autocorrelation models incorporate spatial and historical linkages into multivariate models and, by assessing Galton's problem directly, allow larger samples (White, Burton, and Dow I98 I, Dow, Burton, and White I982, Dow et al. I984), but the effort involved in collating data on

I. (C) 1989 by The Wenner-Gren Foundation for Anthropological Research. All rights reserved ooI I-3204/89/3004-0008 \$I.00. 